\title{
Development and thermal requirements of the Nearctic predator Geocoris punctipes (Hemiptera: Geocoridae) reared at constant and alternating temperatures and fed on Anagasta kuehniella (Lepidoptera: Pyralidae) eggs
}

\author{
Ana M. CALIXTO ${ }^{1}$, VAnda H.P. BUENO ${ }^{1, *}$, Flávio C. MONTES ${ }^{1}$ and Joop C. VAN LENTEREN ${ }^{2}$ \\ ${ }^{1}$ Laboratory of Biological Control, Department of Entomology, Federal University of Lavras, 37200-000, Lavras, MG, Brazil; \\ e-mails: anamaria.calixto@bol.com.br; vhpbueno@den.ufla.br; flaviobiologia2005@hotmail.com \\ ${ }^{2}$ Laboratory of Entomology, Wageningen University, PO Box 8031, 6700 EH Wageningen, The Netherlands; \\ e-mail: joop.vanlenteren@wur.nl
}

Key words. Hemiptera, Geocoridae, Geocoris punctipes, generalist predator, Lepidoptera, Pyralidae, Anagasta kuehniella, eggs, prey, survival, immature developmental time, thermal constant, mass production, biological control, Gelechiidae, Tuta absoluta

\begin{abstract}
Knowledge of the optimal temperatures for development and survival of biological control agents is essential for efficient mass-rearing and introduction of natural enemies in augmentative biological control programs. We studied the effect of constant and alternating temperatures on development and survival of immature stages and the sex ratio at emergence of adults of the Nearctic generalist predator Geocoris punctipes (Say). We also determined its thermal requirements. They were reared in climatic chambers at alternating $\left(21 / 11^{\circ} \mathrm{C}, 24 / 18^{\circ} \mathrm{C}, 27 / 21^{\circ} \mathrm{C}\right.$ and $\left.30 / 26^{\circ} \mathrm{C} \pm 1^{\circ} \mathrm{C}\right)$ and constant temperatures $\left(16.8^{\circ} \mathrm{C}, 21.5^{\circ} \mathrm{C}, 24.5^{\circ} \mathrm{C}\right.$ and $\left.28.3^{\circ} \mathrm{C} \pm 1{ }^{\circ} \mathrm{C}\right)$, RH $70 \pm 10 \%$ and a $14 \mathrm{~h}$ photophase. Survival and development of G. punctipes were the same when reared at constant and alternating temperatures. Five instars were recorded in all temperature regimes. The duration of the egg stage and each instar, as well as that of total larval development were longer, and larval survival lower when reared at $16.8^{\circ} \mathrm{C}, 21 / 11^{\circ} \mathrm{C}, 21.5^{\circ} \mathrm{C}$ and $24 / 18^{\circ} \mathrm{C}$ than at $24.5^{\circ} \mathrm{C}$, $27 / 21^{\circ} \mathrm{C}, 28.3^{\circ} \mathrm{C}$ and $30 / 26^{\circ} \mathrm{C}$. The optimal temperature range for development and survival of G. punctipes is $24.5^{\circ} \mathrm{C}$ to $30^{\circ} \mathrm{C}$, its lower development threshold temperature is $13.5^{\circ} \mathrm{C}$ and its thermal constant $295.9 \mathrm{DD}$. Sex ratios were not significantly different from $1: 1$ male : female ratio in all temperature regimes. There is an excellent match between the temperature regimes at which the prey Tuta absoluta (Meyrick) and predator G. punctipes are active, which indicates that this predator will function well in crops where this pest is present.
\end{abstract}

\section{INTRODUCTION}

Predators of the genus Geocoris are abundant both in nature and agroecosystems (Sweet, 2000). Based on studies carried out in the laboratory, agricultural fields and natural habitats, Schuman et al. (2013) stress the potential of Geocoris spp. as biological control agents. However, the potential of Geocoris spp. in reducing herbivore populations in crops in the field and greenhouses still remains to be demonstrated. Geocoris punctipes (Say) (Hemiptera: Geocoridae) is a predator of aphids, caterpillars and eggs of various Lepidoptera, Bemisia tabaci (Gennadius) and Lygus spp. on several field crops (Richman et al., 1980; Elvin et al., 1983; Tillman \& Mullinix, 2003; Bueno \& Zanuncio, 2009; Bueno \& van Lenteren, 2012). In addition, G. punctipes is frequently recorded on strawberries and vegetables grown in plastic tunnels in the USA (Hagler \& Sanches, 2011) and other studies indicate it is an effective predator of various pests of greenhouse crops (Tamaki \& Weeks, 1972; Pendleton, 2002). Geocoris punctipes was sold on a small scale for controlling Lepidoptera during the 1990s in North America (Bueno \& van Lenteren, 2012; van Lenteren, 2012).

In Brazil, information on the occurrence of Geocorid species on crops is restricted to soybean, cotton, corn and tomatoes (Brondani et al., 2008). On tomato G. punctipes attacks mainly larvae of Tuta absoluta (Meyrick) (Lepidoptera: Gelechiidae) (Bueno et al., 2013). Up until now, there has only been biological information on only one Brazilian geocorid species, Geocoris floridanus Blatchley (Torres et al., 2004). We initiated work on species of Geocoris in order to determine their efficiency as biological control agents, primarily of $T$. absoluta, a very important pest of tomato in Brazil which is now spreading throughout the world (Bueno et al., 2013).

Interest in heteropteran predatory bugs, the number of species commercially available and the areas treated with these insects has increased significantly during the past two decades (Bueno \& van Lenteren, 2012; Calvo et al., 2012; van Lenteren, 2012). Screening of heteropteran predators for use in augmentative biological control is currently an important issue and an important step in their evaluation in determining the effect of temperature on their development, survival and reproduction.

It is well known that temperature affects the physiology and biology of invertebrates, such as their metabolic activity, development, growth, survival and body size (e.g., Campbel et al., 1974; Sinclair et al., 2003; Trudgill et al., 2005; Schuldiner-Harpaz \& Coll, 2013). Most of these ef-

\footnotetext{
* Corresponding author.
} 
fects were determined by rearing them at constant temperatures. However, fluctuating temperatures are typical in natural habitats, and seasonally active species of insect usually exploit intermittent periods of favourable temperatures in order to feed, develop, mate and reproduce, and even repair injuries caused by exposure to low temperature (Colinet et al., 2006, 2007; Lalouette et al., 2007). Bale et al. (2002), among others, stress the importance of measuring survival and development of insects at both constant and fluctuating temperatures. Insect species each have a specific lower developmental temperatures below which they do not develop, and require a certain number of heat units (degree days) in order to complete their development from egg to adult, and quantification of the relationship between insect development and temperature is useful for predicting their seasonal occurrence and population dynamics (Honek et al., 2002). In addition, most of the studies on Geocoris spp., including $G$. punctipes, were done at constant temperatures (Champlain \& Sholdt, 1966; Dunbar \& Bacon, 1972; Crocker et al., 1975; Torres et al., 2004; Schuman et al., 2013). Fluctuating temperatures may affect the development and survival of $G$. punctipes in a different way to constant temperatures, as is reported for other heteropteran predators such as Orius laevigatus (Tommasini \& Benuzzi, 1996) and Anthocoris sibiricus Reuter (Hofsvang, 1976). As there is no published information on the effect of alternating and constant temperature regimes on the generalist predator $G$. punctipes, we determined their effects on the rate of development and survival of the immature stages of this predator fed on the eggs of Anagasta kuehniella (Zeller) and determined this predator's lower developmental threshold and thermal constant.

In order to determine whether a certain natural enemy will function efficiently in a particular agroecosystem it is important to have some knowledge of the effect of local temperature regimes on its biology. Further, this knowledge can be used to determine if the development of prey and predator are likely to be synchronized in the field or a greenhouse, and predict the occurrence and duration of the different life stages of the predator during the development of the crop. This information is also valuable for designing an efficient system for the mass rearing and determining the optimum time for releasing predator in augmentative biological control programs. Next, knowledge of the lower developmental temperature and thermal constant of a natural enemy is important when selecting a control agent for release under optimal environmental conditions, and for predicting whether it will be present when the pest is present and active in the field.

\section{MATERIAL AND METHODS}

\section{Collection and rearing of $G$. punctipes}

Adults of G. punctipes were collected on pigweed plants (Amaranthus viridis $\mathrm{L}$.) in the field in the municipality of Lavras, Minas Gerais, Brazil, located at $21^{\circ} 14^{\prime} \mathrm{S}, 45^{\circ} 00^{\prime} \mathrm{W}$ and $918 \mathrm{~m}$ a.s.l. Plants in flower were brought to the laboratory and their inflorescences tapped over a white tray, which dislodged any insects and those belonging to the genus Geocoris were collected with the aid of a pooter. Individuals were identified under a stereomicro- scope using the key to species of Geocoris spp. by Mead (2008): we only found $G$. punctipes. Next, samples of G. punctipes were sent to a heteropteran specialist (J. Torres, Federal University of Recife, Brazil) who confirmed our identification.

Adults of G. punctipes were placed in glass pots (1.7 1) containing shredded paper towels, pigweed inflorescences placed in a glass tube $(10 \mathrm{~mL})$ with water (moisture source), and eggs of Anagasta kuehniella Zeller (Lepidoptera: Pyralidae) (food source). Both, the paper towels and the pigweed inflorescences were used as oviposition substrates. The number of eggs laid was recorded daily with the aid of a stereomicroscope. Next, the oviposition substrates were transferred to glass Petri dishes $(20 \mathrm{~cm}$ diameter) containing moistened cotton (maintenance of moisture) and eggs of A. kuehniella as food for the larvae. Food was added and the cotton moistened twice per week. Newly-emerged adults were removed from the Petri dishes using a motorized pooter (air compressor model 089/CA, Fanem) and 50 individuals were placed in 1.7 liter glass pots. This procedure provided the stock culture of G. punctipes, which was kept in the Biological Control Laboratory of the Federal University of Lavras (UFLA), Minas Gerais, Brazil. This rearing method is based on one previously described by Bueno et al. (2006) and Bueno (2009) for Orius insidiosus (Say). The cultures were kept at $25 \pm 2^{\circ} \mathrm{C}$, RH $70 \pm 10 \%$ and 14L:10D photoperiod. Monthly, wild individuals collected from pigweed plants in the field were introduced into the laboratory cultures to avoid genetic drift. Eggs laid by $6^{\text {th }}$ generation individuals in stock cultures were used in the experiments.

\section{Constant and alternating temperature regimes}

Temperature regimes used in the experiment were determined from the data of mean, maximum and minimum day and night temperatures recorded in and outside greenhouses in the municipality of Andradas, Minas Gerais state, at $22^{\circ} 04^{\prime} 05^{\prime \prime} \mathrm{S}$ and $46^{\circ} 34^{\prime} 09^{\prime \prime} \mathrm{W}, 920 \mathrm{~m}$ a.s.l. This information on temperatures was then grouped into different combinations of day/night temperatures: $21 / 11^{\circ} \mathrm{C}, 24 / 18^{\circ} \mathrm{C}, 27 / 21^{\circ} \mathrm{C}$ and $30 / 26^{\circ} \mathrm{C}$, all $\pm 1^{\circ} \mathrm{C}$. The constant temperatures corresponding to these combinations were $16.8^{\circ} \mathrm{C}, 21.5^{\circ} \mathrm{C}, 24.5^{\circ} \mathrm{C}$ and $28.3^{\circ} \mathrm{C}$, all $\pm 1^{\circ} \mathrm{C}$ and these temperatures were calculated by determining the weighted average: TM $=(\mathrm{Td} \times \mathrm{Fd})+(\mathrm{Tn} \times \mathrm{Fn}) / \Sigma \mathrm{F}(\mathrm{TM}-$ average temperature, $\mathrm{Td}$ - day-time temperature, $\mathrm{Tn}$ - nigh-time temperature, $\mathrm{Fd}$ - duration of photphase, Fn - duration of scotophase, $\Sigma F$ - summation of photoperiods). The photoperiod was $14 \mathrm{~L}: 10 \mathrm{D}$ in all experiments. These light and temperature regimes were chosen in order to match the regimes in the areas where this predator occurs. The experiment was carried out in climatic chambers in which the RH was $70 \pm 10 \%$.

\section{Development and survival of $G$. punctipes}

Geocoris punctipes eggs that were at most $24 \mathrm{~h}$ old were collected from the stock cultures and placed in glass Petri dishes (20 cm diameter) containing moistened cotton to maintain a sufficiently high humidity. These Petri dishes were kept in climatic chambers kept at one of the different temperature regimes until the larvae hatched. One hundred newly hatched larvae of $G$. punctipes from each temperature regime were put individually in glass Petri dishes $(5 \mathrm{~cm}$ diameter) containing an ad libitum supply of eggs of A. kuehniella (food) and a moistened piece of cotton wool, and reared in the same temperature regime as they were kept in during the egg stage. Water and food were provided every two days. Progress in the development of eggs and larvae was recorded daily.

We calculated development time and survival of the eggs, the number and duration of each instar (by recording the presence of 
TABLE 1. Duration of egg development (days) $( \pm \mathrm{SE})$ and egg survival $(\%)( \pm \mathrm{SE})$ of Geocoris punctipes recorded at alternating and constant temperatures, a RH of $70 \pm 10 \%$ and a $14 \mathrm{~h}$ photophase.

\begin{tabular}{cccl}
\hline Temperature $\left({ }^{\circ} \mathrm{C}\right)$ & $\mathrm{n}^{*}$ & Duration of egg development & Egg survival \\
\hline 16.8 & 30 & $15.4 \pm 0.42 \mathrm{a} *$ & $35.3 \pm 0.20 \mathrm{a}$ \\
$21 / 11$ & 28 & $14.7 \pm 0.37 \mathrm{a}$ & $41.5 \pm 0.27 \mathrm{a}$ \\
21.5 & 48 & $12.4 \pm 0.27 \mathrm{a}$ & $66.5 \pm 0.20 \mathrm{~b}$ \\
$24 / 18$ & 52 & $12.0 \pm 0.18 \mathrm{a}$ & $64.3 \pm 0.15 \mathrm{~b}$ \\
24.5 & 170 & $7.3 \pm 0.14 \mathrm{~b}$ & $89.7 \pm 0.16 \mathrm{c}$ \\
$27 / 21$ & 166 & $7.1 \pm 0.17 \mathrm{~b}$ & $87.6 \pm 0.12 \mathrm{c}$ \\
28.3 & 128 & $8.1 \pm 0.12 \mathrm{~b}$ & $80.7 \pm 0.09 \mathrm{c}$ \\
$30 / 26^{\circ} \mathrm{C}$ & 136 & $8.2 \pm 0.06 \mathrm{~b}$ & $79.4 \pm 0.17 \mathrm{c}$ \\
\hline
\end{tabular}

*n numbers of egg used to determine their development time and survival. ** Means followed by the same letter in a column are not significantly different; non-parametric Kruskal-Wallis test $(\mathrm{p} \leq 0.05)$.

exuviae), survival of each instar, total larval developmental time, total larval survival and sex ratio of the adults at emergence.

\section{Data analysis}

The experiments were carried out using a total random design, with 4 constant and 4 alternating temperatures. Normal distribution of data was checked using the Shapiro-Wilk test ( $p \geq 0.05$ ). As the data on the duration of development of eggs and their survival, duration and survival of instars were not normally distributed, the non-parametric Kruskal-Wallis test was used to compare the means, using the statistical software of the R Development Core Team (2011). Lower developmental threshold (LDT) or base temperature (expressed in degrees Celsius) and thermal constant (K) (expressed in degree-days) were calculated using only constant temperatures and the hyperbolic method (Campbell et al., 1974; Haddad et al., 1999; Bergant \& Trdan, 2006). This method is based on the linear regression $(\mathrm{Y}=\mathrm{a}+\mathrm{bx})$, where $\mathrm{Y}$ is the reciprocal of the development time and $\mathrm{x}$ the temperature. To compare the sex ratio of $G$. punctipes reared in the different temperature regimes, a Chi-square $\left(\chi^{2}\right)$ test with $5 \%$ significance level was used.

\section{RESULTS}

The shortest egg development times (about 8 days) were recorded at $24.5^{\circ} \mathrm{C}, 27 / 21^{\circ} \mathrm{C}, 28.3^{\circ} \mathrm{C}$ and $30 / 26^{\circ} \mathrm{C}$, and the longest (from 12-15 days) at 16.8, 21/11, 21.5 and $24 / 18^{\circ} \mathrm{C}$ (Kruskal-Wallis, $\mathrm{H}=34.4513$, $\mathrm{df}=7, \mathrm{p}<0.0001$ ). Egg survival was significantly higher at $24.5^{\circ} \mathrm{C}, 27 / 21^{\circ} \mathrm{C}$, $28.3^{\circ} \mathrm{C}$ and $30 / 26^{\circ} \mathrm{C}$ than at $16.8^{\circ} \mathrm{C}$ and $21 / 11^{\circ} \mathrm{C}, 21.5^{\circ} \mathrm{C}$ and $24 / 18^{\circ} \mathrm{C}$ (Table 1: Kruskal-Wallis, $\mathrm{H}=27.3608$, $\mathrm{df}=$ $7, \mathrm{p}=0.0002)$

The same number of larval instars was recorded for $G$. punctipes in all the temperature regimes, whether alternating or constant (Table 2). A longer total larval development was recorded at $16.8^{\circ} \mathrm{C}$ and $21 / 11^{\circ} \mathrm{C}$ than in the other temperature regimes (Table 2). No significant difference in the for development times of the different instars was recorded at $24.5^{\circ} \mathrm{C}, 27 / 21^{\circ} \mathrm{C}, 28.3^{\circ} \mathrm{C}$ and $30 / 26^{\circ} \mathrm{C}$ (Table 2) (Kruskal-Wallis, first instar: $\mathrm{H}=16.2145, \mathrm{df}=7, \mathrm{p}=$ 0.1001; second instar: $\mathrm{H}=23.0827$, $\mathrm{df}=7, \mathrm{p}=0.2113$; third instar: $\mathrm{H}=12.0654$, $\mathrm{df}=7, \mathrm{p}=0.1101$; fourth instar: $\mathrm{H}=30.1475$, $\mathrm{df}=7, \mathrm{p}=0.2021$ and fifth instar: $\mathrm{H}$ $=26.1749$, df $=7, p=0.103)$. At $24 / 18^{\circ} \mathrm{C}$ the development time of the first instar (8.8 days) (Kruskal-Wallis, $\mathrm{H}=$ 24.1532 , $\mathrm{df}=7, \mathrm{p}=0.0009$ ) was significantly shorter than that of all the other instars reared at the same temperature (Table 2).

TABLE 2. Duration of the different instars (days) ( \pm SE) of Geocoris punctipes recorded at constant and alternating temperatures, a $\mathrm{RH}$ of $70 \pm 10 \%$ and a $14 \mathrm{~h}$ photophase.

\begin{tabular}{|c|c|c|c|c|c|}
\hline $\mathrm{T}\left({ }^{\circ} \mathrm{C}\right)$ & $1^{\text {st }}$ instar & $2^{\text {nd }}$ instar & $3^{\text {rd }}$ instar & $4^{\text {th }}$ instar & $5^{\text {th }}$ instar \\
\hline 16.8 & $\begin{array}{c}15.9 \pm 0.10 \mathrm{aA}^{*} \\
\left(\mathrm{n}=100^{* *}\right)\end{array}$ & $\begin{array}{c}17.8 \pm 0.13 \mathrm{aA} \\
(\mathrm{n}=74)\end{array}$ & $\begin{array}{c}18.2 \pm 0.14 \mathrm{aA} \\
(\mathrm{n}=60)\end{array}$ & $\begin{array}{c}18.5 \pm 0.18 \mathrm{aA} \\
\quad(\mathrm{n}=44)\end{array}$ & $\begin{array}{c}19.3 \pm 0.81 \mathrm{aA} \\
(\mathrm{n}=28)\end{array}$ \\
\hline $21 / 11$ & $\begin{array}{c}15.6 \pm 0.07 \mathrm{aA} \\
(\mathrm{n}=100)\end{array}$ & $\begin{array}{c}16.1 \pm 0.10 \mathrm{aA} \\
(\mathrm{n}=76)\end{array}$ & $\begin{array}{c}17.3 \pm 0.17 \mathrm{aA} \\
(\mathrm{n}=58)\end{array}$ & $\begin{array}{c}16.6 \pm 0.19 \mathrm{aA} \\
(\mathrm{n}=42)\end{array}$ & $\begin{array}{c}18.8 \pm 0.19 \mathrm{aA} \\
\quad(\mathrm{n}=32)\end{array}$ \\
\hline 21.5 & $\begin{array}{c}11.5 \pm 0.11 \mathrm{bA} \\
\quad(\mathrm{n}=100)\end{array}$ & $\begin{array}{c}12.6 \pm 0.23 \mathrm{bA} \\
(\mathrm{n}=81)\end{array}$ & $\begin{array}{c}10.7 \pm 0.12 \mathrm{bA} \\
(\mathrm{n}=67)\end{array}$ & $\begin{array}{c}10.8 \pm 0.21 \mathrm{bA} \\
(\mathrm{n}=55)\end{array}$ & $\begin{array}{c}11.2 \pm 0.12 \mathrm{bA} \\
(\mathrm{n}=39)\end{array}$ \\
\hline $24 / 18$ & $\begin{array}{c}8.8 \pm 0.09 \mathrm{bA} \\
(\mathrm{n}=100)\end{array}$ & $\begin{array}{c}10.6 \pm 0.12 \mathrm{bB} \\
\quad(\mathrm{n}=82)\end{array}$ & $\begin{array}{c}10.8 \pm 0.11 b B \\
(\mathrm{n}=68)\end{array}$ & $\begin{array}{c}11.0 \pm 0.12 \mathrm{bB} \\
(\mathrm{n}=54)\end{array}$ & $\begin{array}{c}11.5 \pm 0.24 \mathrm{bB} \\
(\mathrm{n}=42)\end{array}$ \\
\hline 24.5 & $\begin{array}{c}3.7 \pm 0.13 \mathrm{cA} \\
(\mathrm{n}=100)\end{array}$ & $\begin{array}{c}3.6 \pm 0.07 \mathrm{cA} \\
(\mathrm{n}=91)\end{array}$ & $\begin{array}{c}3.4 \pm 0.13 \mathrm{cA} \\
(\mathrm{n}=79)\end{array}$ & $\begin{array}{c}4.0 \pm 0.14 \mathrm{cA} \\
(\mathrm{n}=71)\end{array}$ & $\begin{array}{c}4.2 \pm 0.18 \mathrm{cA} \\
(\mathrm{n}=63)\end{array}$ \\
\hline $27 / 21$ & $\begin{array}{c}3.5 \pm 0.07 \mathrm{cA} \\
(\mathrm{n}=100)\end{array}$ & $\begin{array}{c}3.6 \pm 0.06 \mathrm{cA} \\
(\mathrm{n}=92)\end{array}$ & $\begin{array}{c}3.9 \pm 0.15 \mathrm{cA} \\
(\mathrm{n}=81)\end{array}$ & $\begin{array}{c}4.1 \pm 0.16 \mathrm{cA} \\
(\mathrm{n}=75)\end{array}$ & $\begin{array}{c}4.3 \pm 0.12 \mathrm{cA} \\
\quad(\mathrm{n}=66)\end{array}$ \\
\hline 28.3 & $\begin{array}{c}4.4 \pm 0.08 \mathrm{cA} \\
(\mathrm{n}=100)\end{array}$ & $\begin{array}{c}5.1 \pm 0.08 \mathrm{cA} \\
(\mathrm{n}=88)\end{array}$ & $\begin{array}{c}4.5 \pm 0.09 \mathrm{cA} \\
(\mathrm{n}=78)\end{array}$ & $\begin{array}{c}4.1 \pm 0.08 \mathrm{cA} \\
(\mathrm{n}=70)\end{array}$ & $\begin{array}{c}5.2 \pm 0.10 \mathrm{cA} \\
(\mathrm{n}=62)\end{array}$ \\
\hline $30 / 26$ & $\begin{array}{c}3.9 \pm 0.06 \mathrm{cA} \\
(\mathrm{n}=100)\end{array}$ & $\begin{array}{c}5.2 \pm 0.09 \mathrm{cA} \\
(\mathrm{n}=87)\end{array}$ & $\begin{array}{c}3.8 \pm 0.08 \mathrm{cA} \\
(\mathrm{n}=79)\end{array}$ & $\begin{array}{c}3.8 \pm 0.09 \mathrm{cA} \\
(\mathrm{n}=69)\end{array}$ & $\begin{array}{c}5.0 \pm 0.12 \mathrm{cA} \\
(\mathrm{n}=60)\end{array}$ \\
\hline
\end{tabular}

* Means followed by the same capital letter in a line and by the same lower case letter in a column are not significantly different; nonparametric Kruskal-Wallis test $(\mathrm{p} \leq 0.05) . * * \mathrm{n}=$ number of individuals. 

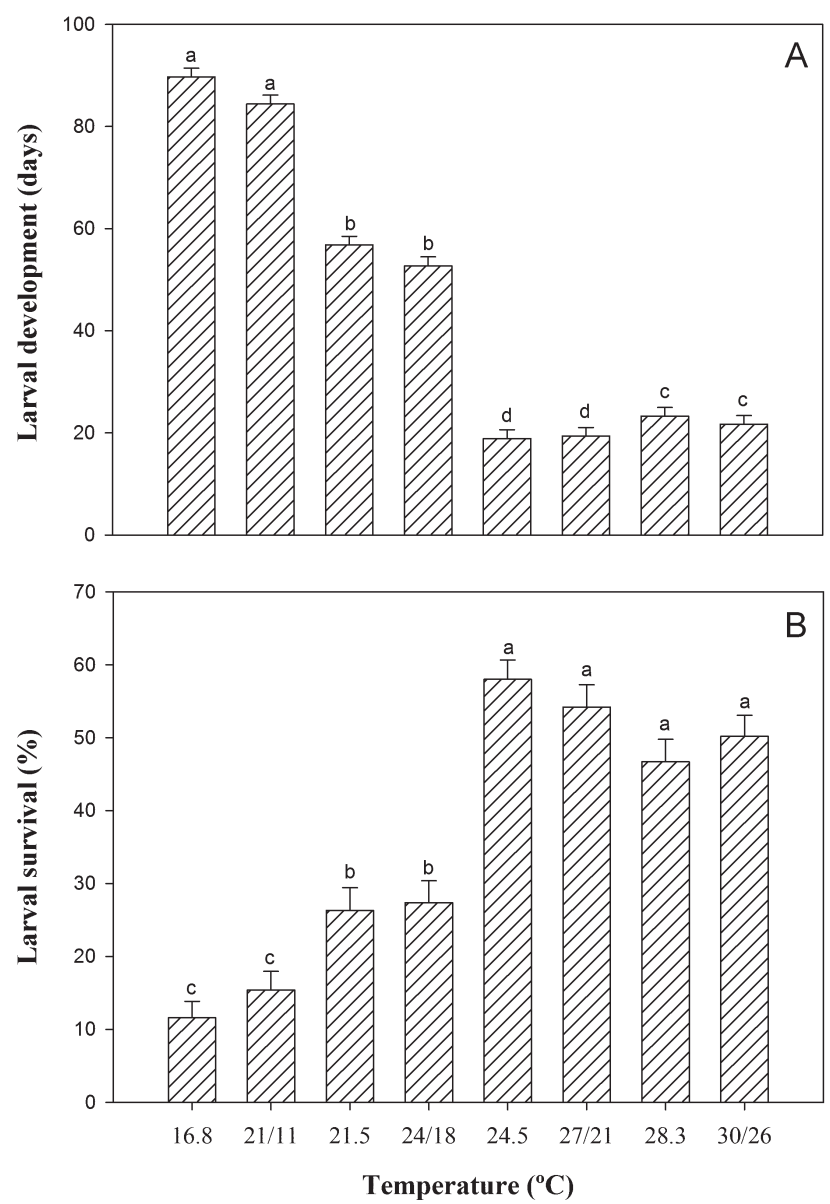

Fig. 1. Larval development times (A) and survival (B) for Geocoris punctipes reared at constant and alternating temperatures.

Larval development time of G. punctipes decreased with increase in temperature (Table 2, Fig. 1A). Larval development was significantly longer (more than 80 days) at $16.8^{\circ} \mathrm{C}$ and $21 / 11^{\circ} \mathrm{C}$ than at the other temperatures (Kruskal-Wallis, $\mathrm{H}=26.1749$, $\mathrm{df}=7, \mathrm{p}<0.0001$ ). At $24.5^{\circ} \mathrm{C}$ and $27 / 21^{\circ} \mathrm{C}$, the larval development time was about 19 days and significantly shorter than at all the other temperatures. At $28.3^{\circ} \mathrm{C}$ and $30 / 26^{\circ} \mathrm{C}$ the larval development was 23.3 and 21.7 days, respectively (Table 2).

The development rate of $G$. punctipes as a function of temperature is presented in Table 3. The lower developmental temperatures or base temperatures $(\mathrm{Tb})$ and thermal constants (K) differ for the egg (Fig. 2A), each instar and total larval development (Fig. 2B) (Table 3). The lowest development threshold was recorded for the egg stage
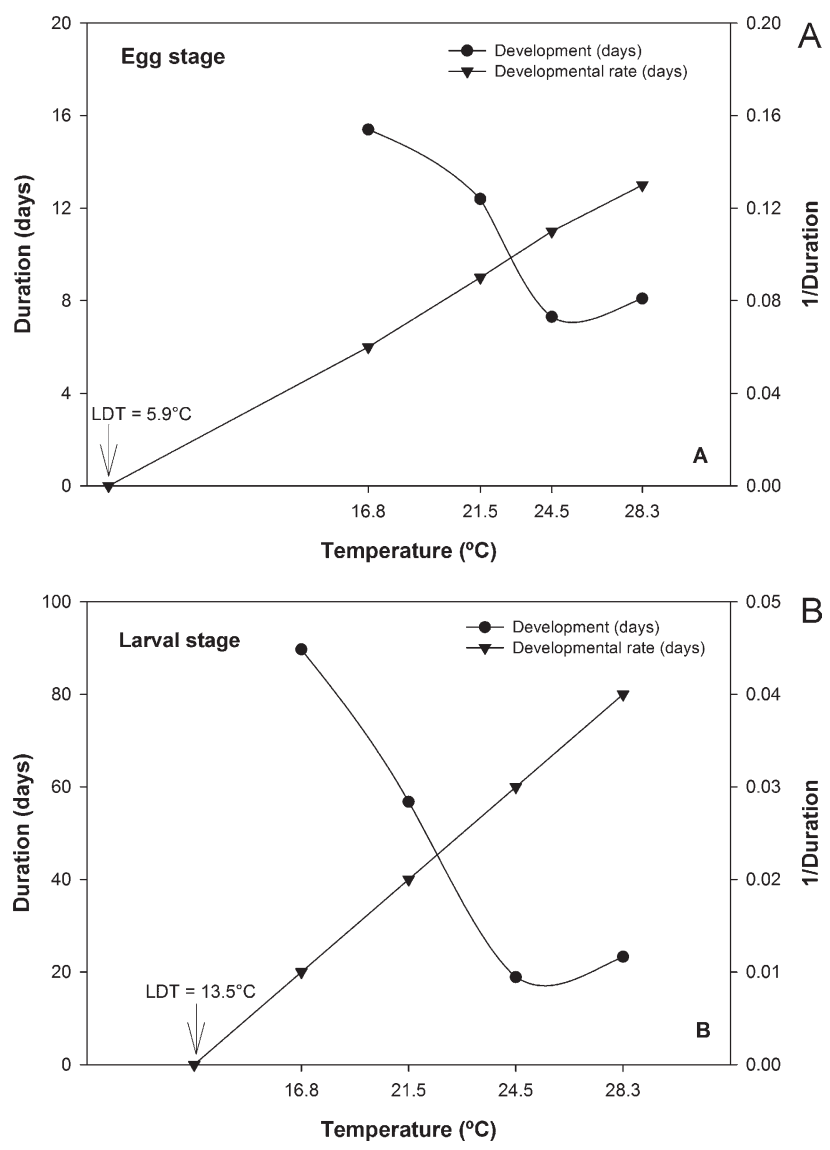

Fig. 2. Relationships between both the duration of development (days) and developmental rate (1/days), and temperature of eggs (A) and larval stages (B) of Geocoris punctipes.

$\left(5.9^{\circ} \mathrm{C}\right)$ and the highest for the fourth instar $\left(14.3^{\circ} \mathrm{C}\right)$. The $4^{\text {th }}$ instar has the smallest thermal constant (52.9 degreedays). The thermal constants of the individual larval instars of G. punctipes varied from 52.9 to 67.4 and the thermal constant for the total larval stage was to 295.9 DD (degreedays) (Table 3 ).

The percentage survival of the different stages was also affected by temperature. At $16.8^{\circ} \mathrm{C}, 21 / 11^{\circ} \mathrm{C}, 21.5^{\circ} \mathrm{C}$ and $24 / 18^{\circ} \mathrm{C}$, the percentage survival was significantly lower (Kruskal-Wallis, first instar: $\mathrm{H}=32.7789$, $\mathrm{df}=7, \mathrm{p}<$ 0.0001 ; second instar: $\mathrm{H}=21.1274$, $\mathrm{df}=7, \mathrm{p}=0.0001$; third instar: $\mathrm{H}=8.3226, \mathrm{df}=7, \mathrm{p}<0.0001$; fourth instar: $\mathrm{H}$ $=17.5531, \mathrm{df}=7, \mathrm{p}<0.0001$ and fifth instar: $\mathrm{H}=6.4523$, $\mathrm{df}=7, \mathrm{p}<0.0001$ ) for all instars of $G$. punctipes than at the higher temperatures (Table 4). Total percentage larval

TABLE 3. The regression equations and their correlation coefficients $\left(\mathrm{R}^{2}\right)$ used to calculate the lower developmental thresholds (LDT) and thermal constants $(\mathrm{K})$ for the different developmental stages of Geocoris punctipes.

\begin{tabular}{ccccc}
\hline Stages/Instars & $\mathrm{LDT}\left({ }^{\circ} \mathrm{C}\right)$ & $\mathrm{K}(\mathrm{DD})$ & Equations $(1 / \mathrm{D})$ & $\mathrm{R}^{2}(\%)$ \\
\hline Egg & 5.9 & 165.6 & $-0.035987+0.006037 \mathrm{X}$ & 98.0 \\
$1^{\text {st }}$ instar & 13.4 & 57.9 & $-0.231854+0.017251 \mathrm{X}$ & 95.4 \\
$2^{\text {nd }}$ instar & 13.1 & 62.9 & $-0.209605+0.015892 \mathrm{X}$ & 96.2 \\
$3^{\text {rd }}$ instar & 13.6 & 55.0 & $-0.247874+0.018180 \mathrm{X}$ & 94.5 \\
$4^{\text {th }}$ instar & 14.3 & 52.9 & $-0.270034+0.018887 \mathrm{X}$ & 99.0 \\
$5^{\text {th }}$ instar & 13.1 & 67.4 & $-0.194690+0.014821 \mathrm{X}$ & 97.0 \\
Total larval stage & 13.5 & 295.9 & $-0.045814+0.003379 \mathrm{X}$ & 99.1 \\
\hline
\end{tabular}


TABLE 4. Survival (\%) ( \pm SE) of the different instars of Geocoris punctipes recorded at different constant and alternating temperatures, a RH of $70 \pm 10 \%$ and a $14 \mathrm{~h}$ photophase. Values for $\mathrm{n}$ are the same as in Table 2.

\begin{tabular}{cccccc}
\hline $\mathrm{T}\left({ }^{\circ} \mathrm{C}\right)$ & $1^{\text {st }}$ instar & $2^{\text {nd }}$ instar & $3^{\text {rd }}$ instar & $4^{\text {th }}$ instar & $5^{\text {th }}$ instar \\
\hline 16.8 & $74.2 \pm 0.30 \mathrm{aA}$ & $80.8 \pm 0.76 \mathrm{aA}$ & $50.7 \pm 0.25 \mathrm{aB}$ & $53.2 \pm 0.22 \mathrm{aB}$ & $30.1 \pm 0.19 \mathrm{aC}$ \\
$21 / 11$ & $78.4 \pm 0.28 \mathrm{aA}$ & $77.8 \pm 0.31 \mathrm{aA}$ & $55.2 \pm 0.26 \mathrm{aB}$ & $54.3 \pm 0.18 \mathrm{aB}$ & $29.4 \pm 0.17 \mathrm{aC}$ \\
21.5 & $79.3 \pm 0.20 \mathrm{aA}$ & $70.2 \pm 0.21 \mathrm{aA}$ & $75.0 \pm 0.25 \mathrm{bA}$ & $70.0 \pm 0.14 \mathrm{bA}$ & $60.0 \pm 0.20 \mathrm{bA}$ \\
$24 / 18$ & $84.0 \pm 0.19 \mathrm{aA}$ & $72.5 \pm 0.10 \mathrm{aA}$ & $70.0 \pm 0.21 \mathrm{bA}$ & $72.0 \pm 0.10 \mathrm{bA}$ & $61.0 \pm 0.21 \mathrm{bA}$ \\
24.5 & $94.1 \pm 0.31 \mathrm{bA}$ & $80.7 \pm 0.15 \mathrm{aB}$ & $83.0 \pm 0.24 \mathrm{bB}$ & $80.0 \pm 0.13 \mathrm{bB}$ & $78.0 \pm 0.11 \mathrm{bB}$ \\
$27 / 21$ & $90.6 \pm 0.24 \mathrm{bA}$ & $91.4 \pm 0.09 \mathrm{aA}$ & $84.0 \pm 0.09 \mathrm{bB}$ & $82.0 \pm 0.09 \mathrm{bB}$ & $76.0 \pm 0.13 \mathrm{bB}$ \\
28.3 & $90.1 \pm 0.23 \mathrm{bA}$ & $84.3 \pm 0.26 \mathrm{aA}$ & $77.1 \pm 0.20 \mathrm{bA}$ & $68.7 \pm 0.28 \mathrm{bB}$ & $64.0 \pm 0.16 \mathrm{bB}$ \\
$30 / 26$ & $91.3 \pm 0.30 \mathrm{bA}$ & $86.2 \pm 0.28 \mathrm{aA}$ & $80.0 \pm 0.24 \mathrm{bA}$ & $72.5 \pm 0.31 \mathrm{bB}$ & $67.5 \pm 0.19 \mathrm{bB}$ \\
\hline
\end{tabular}

* Means followed by the same capital letter in a line and by the same lower case letter in a column are not significantly different; nonparametric Kruskal-Wallis test $(\mathrm{p} \leq 0.05)$.

survival was also significantly lower at the lower temperatures (Kruskal-Wallis, $\mathrm{H}=23.1439$, $\mathrm{df}=7, \mathrm{p}=0.0001$ ). At $16.8^{\circ} \mathrm{C}$ and $21 / 11^{\circ} \mathrm{C}$ the percentage larval survival was $11.6 \%$ and $15.4 \%$, respectively (Table 4 , Fig. 1B), with that of the fifth instar particularly low. The survival of larvae of the different instars reared at the same temperature differed, particularly at $16.8^{\circ} \mathrm{C}$ and $21 / 11^{\circ} \mathrm{C}$. At $27 / 21^{\circ} \mathrm{C}$, $24.5^{\circ} \mathrm{C}, 30 / 26^{\circ} \mathrm{C}$ and $28.3^{\circ} \mathrm{C} 1^{\text {st }}$ instar survival was highest at about $90 \%$.

Sex ratios did not differ significantly from a $1: 1$ male : female ratio $\left(\chi^{2}=5.72, \mathrm{p}=0.0534\right)$ in all temperature regimes (Table 5).

\section{DISCUSSION}

Temperature affected the rate of development and survival of immature G. punctipes, but alternating day and night temperatures resulted in the same survival and development times as their respective constant average temperatures. The latter finding will make mass rearing and predator release programs easier as no corrections for development and survival are needed when working with this predator when temperatures fluctuate approximately between 17 and $30^{\circ} \mathrm{C}$. In contrast, there are reports that other heteropteran predators either develop significantly faster (e.g. A. sibiricus; Hofsvang, 1976) or slower (e.g. O. laevigatus; Tommasini \& Benuzzi, 1996) in fluctuating than equivalent constant temperature conditions. However, one needs to consider that the effect of fluctuating temperature on the development time of a pest or natural enemy depends on the optimum temperature and the upper and lower development threshold of the organisms in question (Jakobsen et al., 2006).

Geocoris punctipes eggs and larvae kept at $16.8^{\circ} \mathrm{C}$, $21 / 11^{\circ} \mathrm{C}, 21.5^{\circ} \mathrm{C}$ and $24 / 18^{\circ} \mathrm{C}$ took longer to complete their development than at higher temperatures. Slower development at low temperatures is a general finding in

TABLE 5. Sex ratio of Geocoris punctipes recorded at constant and alternating temperatures, a RH of $70 \pm 10 \%$ and a $14 \mathrm{~h}$ photophase.

\begin{tabular}{lcccccccc}
\hline & \multicolumn{7}{c}{ Temperatures $\left({ }^{\circ} \mathrm{C}\right)$} \\
\cline { 2 - 8 } & 16.8 & $21 / 11$ & 21.5 & $24 / 18$ & 24.5 & $27 / 21$ & 28.3 & $30 / 26$ \\
\hline Sex ratio & $0.54 *$ & 0.46 & 0.52 & 0.50 & 0.54 & 0.52 & 0.48 & 0.48 \\
\hline$*$ They do not differ significantly from a $1: 1$ (Chi-Square test: $\chi^{2}$ \\
$=5.72, \mathrm{p}=0.0534)$.
\end{tabular}

insects. Roy et al. (2002) stressed that low temperatures lengthen development time because they reduce metabolic rate. These effects may partly explain the high mortality of larvae of $G$. punctipes we recorded at temperatures below $24^{\circ} \mathrm{C}$.

The developmental time of the various instars of $G$. punctipes recorded at different temperatures are similar to those reported at constant temperatures for $G$. punctipes reared at $25^{\circ} \mathrm{C}$ and fed on Spodoptera frugiperda (J.E. Smith) (Champlain \& Sholdt, 1967a) and at $30^{\circ} \mathrm{C}$, fed on Phtorimaea operculella (Zeller) (Dunbar \& Bacon, 1972). The values are also similar to those for Geocoris floridanus Blatchley reared at $26^{\circ} \mathrm{C}$ [3-7 days and fed on eggs of $\mathrm{Hel}$ icoverpa zea (Boddie)] (Torres et al., 2004), and Geocoris lubra Kirkaldy, [3 to 8 days at $27^{\circ} \mathrm{C}$ and fed on eggs of Helicoverpa armigera (Hübner)] (Mansfield et al., 2007). In addition, the total durations of larval development of $G$. punctipes at high temperatures are similar to those reported by Dunbar \& Bacon (1972) for G. punctipes (21.8 days for females and 22.2 days for males) and by Torres et al. (2004) for G. floridanus (21.1 days). Populations of geocorids are likely to develop more rapidly in warm than in cold spring (Tamaki \& Weeks 1972, Champlain \& Sholdt, $1967 \mathrm{a}, \mathrm{b})$. The development rate from egg to adult of Geocoris spp. correlates positively with temperatures between $21^{\circ} \mathrm{C}$ and $37^{\circ} \mathrm{C}$, but may differ considerably among species (Schuman et al., 2013) and with the quality of the prey.

Survival of individual larval instars of $G$. punctipes was higher when reared at temperatures above $24^{\circ} \mathrm{C}$, but even then survival was not higher than $60 \%$. Mansfield et al. (2007) report survival values of $89 \%$ for individual larval stages and $64.8 \%$ for the total larval development of G. lubra reared at $27^{\circ} \mathrm{C}$. These higher values may be due to the use of a different methodology and/or temperature, food or photoperiod. No plant tissue was added to the experimental arenas in our study and this may explain the low survival rates. Plant materials can provide nutritional resources that enhance omnivore survival relative to water alone (e.g. Tamaki \& Weeks, 1972), in addition to providing a suitable oviposition substrate for heteropteran predators (Bueno \& van Lenteren, 2012). Plant material on its own is insufficient for the full development of larvae of Geocoris spp. (Stoner, 1930; York, 1944; Sweet, 1960; Eubanks \& Denno, 1999). Therefore, an adequate diet should 
contain both plant material and prey (aphids, lepidopteran eggs, etc.). Schuman et al. (2013) mentioned that diet plays a significant role in the development and survival of Geocoris spp. Several species of prey are mentioned as suitable food, e.g. T. absoluta, B. tabaci, aphids (such as Myzus persicae (Sulzer) and Aphis gossypii Glover), thrips Frankliniella occidentalis (Pergande) and mites (Crocker \& Whitcomb, 1980; Cohen \& Byrne, 1992, Bueno et al., 2013), but our study is the first to use eggs of A. kuehniella as prey, which can be easily mass produced. Because of their high nitrogen content, lepidopteran eggs have a high nutritional quality for several heteropteran predatory bugs compared to other insect foods (Cohen, 1989; Bonte \& De Clercq, 2010; Calixto et al., 2013). Ferkovich et al. (2007) report that the protein content of the eggs of A. kuehniella is higher than that of the eggs of several other species of Lepidoptera.

The lower developmental thresholds of the different stages of development of $G$. punctipes varied between 13.1 to $14.3^{\circ} \mathrm{C}$ and the thermal constants between 5.5 to $67.4 \mathrm{de}-$ gree-days. Our results for the lower developmental threshold for the larval development $\left(13.5^{\circ} \mathrm{C}\right)$ of $G$. punctipes are similar to those recorded for other important commercial heteropteran predators such as Nesidiocoris tenuis Reuter $\left(12.9^{\circ} \mathrm{C}\right)$ (Hughes et al., 2009), Macrolophus pygmaeus (Rambur) (range $8.80^{\circ} \mathrm{C}-10.06^{\circ} \mathrm{C}$ ) (Perdikis \& Lykouressis, 2002), Orius laevigatus (Fieber) $\left(11.3^{\circ} \mathrm{C}\right)$ (Sanchez \& Lacasa, 2002) and $O$. insidiosus (range $12.27^{\circ} \mathrm{C}-13.03^{\circ} \mathrm{C}$ ) (Mendes et al., 2005). The lower developmental threshold is probably similar for all the developmental stages within a population and species (Honek et al., 2002), and probably also for taxonomically related group of species (Dixon et al., 1997). In contrast, the thermal constant is plastic and reflects variation in environmental conditions other than temperature, including for example, food quality, humidity and photoperiod.

The relatively high lower developmental threshold of the larvae of $G$. punctipes $\left(13.5^{\circ} \mathrm{C}\right)$ combined with the high mortality below $24^{\circ} \mathrm{C}$ indicates that this species is adapted to (sub-)tropical climates. We realize that using linear relationships as we did, is an approximation of the real dependence of insect development on temperature, and that other factors can significantly influence development (Bergant $\&$ Trdan, 2006), and the thermal constant (Honek et al., 2002).

Two important criteria for evaluating the efficiency of a natural enemy are related to temperature: the natural enemy should be active during the period the pest is present and should be adapted to the local climate (van Lenteren, 2010). Interestingly, T. absoluta is active within a temperature range of $19.7^{\circ} \mathrm{C}$ to $27.1^{\circ} \mathrm{C}$ (Barrientos et al., 1998). Thus, the pest $T$. absoluta develops over the same temperature range as the immature stages of its predator $G$. punctipes. This climate matching between pest and predator is a positive finding, because it means that predators can establish and develop in crops where prey is present. Knowledge of the temperature requirements of candidate biological control agents, in particular their cold tolerance, may help predict whether they will become established and their potential for spreading following releases into new areas (Manrique et al., 2008), and whether their appearance will be synchronized with that of its prey, in this case T. $a b$ soluta. Further improvement of our rearing methodology will optimize the laboratory production of $G$. punctipes. Currently, very limited information is available on the biology, ecology and effectiveness of the biological control agent Geocoris spp. native to Brazil and this study is a first step in obtaining such information.

In conclusion egg and larval survival and development time of immature stages of $G$. punctipes are strongly affected by temperature, but that alternating temperatures within a range of $10^{\circ} \mathrm{C}$ around a certain average temperature results in similar developmental and survival values as the constant average temperature. Further, we conclude that $G$. punctipes is adapted to (sub-)tropical climates. Our results will be used to further develop and improve the mass rearing methods for this predator, estimate where this predator can be successfully established in the field or greenhouses, and synchronize field releases with the development of its prey.

ACKNOWLEDGEMENTS. The authors thank the National Council for Scientific Research (CNPq), Coordination for the Improvement of Higher Education Personnel (CAPES) and Foundation for Support Research of Minas Gerais (FAPEMIG) for funding this project.

\section{REFERENCES}

Bale J.S., Masters G.J., Hodkinson I.D., Awmack C. \& Bezemer T.M. 2002: Herbivory in global climate change research: direct effects of rising temperature on insect herbivores. - Glob. Change Biol. 8: 1-16.

Barrientos Z.R., Apablasa H.J., Norero S.A. \& Estay P.P. 1998: Threshold temperature and thermal constant for development of the South American tomato moth, Tuta absoluta (Lepidoptera: Gelechiidae). - Cienc. Investig. Agr. 25: 133-137 [in Spanish].

Bergant K. \& TRDAN S. 2006: How reliable are thermal constants for insect development when estimated from laboratory experiments. - Entomol. Exp. Appl. 120: 251-256.

Bonte M. \& De Clerce P. 2010: Influence of diet on the predation rate of Orius laevigatus on Frankliniella occidentalis. BioControl 55: 625-629.

Brondani D., Guedes J.V.C., Farias J.R., Bigolin M., Karlec F. \& Lopes S.J. 2008: Ocorrência de insetos na parte aérea da soja em função do manejo de plantas daninhas em cultivar convencional e geneticamente modificada resistente a glyphosate. [Occurrence of insects in the aerial part of soybean in function of the weed control systems and conventional and genetically modified herbicide-tolerant varieties.] - Ciênc. Rural 38: 2132-2137 [in Portuguese].

BuEno V.H.P. 2009: Desenvolvimento e criação massal de percevejos predadores Orius. [Development and mass-rearing of Orius predatory bugs.] In Bueno V.H.P. (ed.): Controle biológico de pragas: Produção massal e controle de qualidade. [Biological Control of Pests: Mass Production and Quality Control.] UFLA, Lavras, pp. 33-76 [in Portuguese].

Bueno V.H.P. \& Van Lenteren J.C. 2012: Predatory bugs (Heteroptera). In Panizzi A.R. \& Parra J.R.P. (eds): Insect Bioecolo- 
gy and Nutrition for Integrated Pest Management. CRC Press, Boca Raton, pp. 51-70.

Bueno V.H.P. \& Zanuncio J.C. 2009: Percevejos predadores (Heteroptera). [Predatory bugs (Heteroptera).] In Panizzi A.R. \& Parra J.R.P. (eds): Bioecologia e nutrição de insetos - base para o manejo integrado de pragas. [Bioecology and Insect Nutrition - Base for Integrated Pest Management.] EMBRAPA Informação Tecnológica, Brasilia, pp. 875-930 [in Portuguese].

Bueno V.H.P., Mendes S.M. \& Carvalho L.M. 2006: Evaluation of a rearing-method for the predator Orius insidiosus. - Bull. Insectol. 59: 1-6.

Bueno V.H.P., Van Lenteren J.C., Lins JR. J.C., Calixto A.M., Montes F.C., Silva D.B., Santiago L.D. \& Pérez L.M. 2013: New records of Tuta absoluta (Meyrick) (Lepidoptera: Gelechiidae) predation by Brazilian hemipteran predatory bugs. J. Appl. Entomol. 137: 29-34.

Calixto A.M., Bueno V.H.P., Montes F.C., Silva A.C. \& Van LENTEREN J.C. 2013: Effect of different diets on reproduction, longevity and predation capacity of Orius insidiosus (Say) (Hemiptera: Anthocoridae). - Biocontr. Sci. Tech. 23: 1245-1255.

Calvo F.J., Lorente M.J., Stansly P.A. \& Belda J.E. 2012: Preplant release of Nesidiocoris tenuis and supplementary tactics for control of Tuta absoluta and Bemisa tabaci in greenhouse tomato. - Entomol. Exp. Appl. 143: 111-119.

Campbell A., Frazer B.D., Gilbert N., Gutierrez A.P. \& MACKAUER M. 1974: Temperature requirements of some aphids and their parasites. - J. Appl. Ecol. 11: 431-438.

Champlain R.A. \& Sholdt L.L. 1966: Rearing Geocoris punctipes, a Lygus bug predator, in the laboratory. - J. Econ. Entomol. 59: 1301-1305.

Champlain R.A. \& Sholdt L.L. 1967a: Life history of Geocoris punctipes (Hemiptera: Lygaeidae) in the laboratory. - Ann. Entomol. Soc. Am. 60: 881-883.

Champlain R.A. \& Sholdt L.L. 1967b: Temperature range for development immature stages of Geocoris punctipes (Hemiptera: Lygaeidae). - Ann. Entomol. Soc. Am. 60: 883-885.

CoHen A.C. 1989: Ingestion efficiency and protein consumption by a heteropteran predator. - Ann. Entomol. Soc. Am. 82: 495-499.

Cohen A.C. \& Byrne D.N. 1992: Geocoris puntipes as a predator of Bemisia tabaci. - Entomol. Exp. Appl. 64: 195-202.

Collinet H., Renault D., Hance T. \& Vernon P. 2006: The impact of fluctuating thermal regimes on the survival of a coldexposed parasitic wasp, Aphidius colemani. - Physiol. Entomol. 31: 234-240.

Collinet H., Hance T., Vernon P., Bouchereau A. \& Renault D. 2007: Does fluctuating thermal regime trigger free amino acid production in the parasitic wasp Aphidius colemani (Hymenoptera: Aphidiinae). — Bioch. Physiol. (A) 147: 484-492.

Crocker R.L. \& Whitcomb W.H. 1980: Feeding niches of the big-eyed-bugs Geocoris bullatus, G. punctipes and G. uliginosus (Hemiptera: Lygaeidae, Geocorinae). —Environ. Entomol. 9: $508-513$

Crocker R.L., Whitcomb W.H. \& Ray R.M. 1975: Effects of sex, developmental stage and temperature on predation by Geocoris punctipes. - Environ. Entomol. 4: 531-534.

Dixon A.F.G., Hemptinne J.L. \& Kindlmann P. 1997: Effectiveness of ladybirds as biological control agents: patterns and processes. - Entomophaga 42: 71-83.

DunBar D.M. \& BACON O.G. 1972: Influence of temperature on development and reproduction of Geocoris atricolor, G. pallens and G. punctipes (Heteroptera: Lygaeidae) from California. — Environ. Entomol. 1: 596-599.
Elvin M.K., Stimac J.L. \& Whitcomb W.H. 1983: Estimating rates of arthropod preparation on velvet-bean caterpillar larvae in soybeans. - Fla Entomol. 66: 320-330.

Eubanks M.D. \& Denno R.F. 1999: The ecological consequences of variation in plants and prey for an omnivorous insect. Ecology 80: 1253-1266.

Ferkovich S.M., Venkatesan T., Shaphiro J.P. \& Carpenter J.E. 2007: Presentation of artificial diet: Effects of composition and size of prey and diet domes on egg production by Orius insidiosus (Heteroptera: Anthocoridae). — Fla Entomol. 90: 502-508.

Haddad M.L., Parra J.R.P. \& Morales R.C.B. 1999: Methods to Estimate the Low and Superior Thermal Limits of Insect Development. Fundação de Estudos Agrários "Luiz de Queiroz", Piracicaba, 29 pp. [in Portuguese].

Hagler J. \& SAnchez N. 2011: Geocoris spp. (Heteroptera: Lygaeidae). Available at http://www.biocontrol.entomology. cornell.edu/predators/Geocoris. Accessed on February 3, 2014.

HoFsvaNG L. 1976: Development of Anthocoris sibiricus Reuter (Het., Anthocoridae) at constant and fluctuating temperatures with the green peach aphid Myzus persicae (Sulzer) as prey. Norw. J. Entomol. 23: 29-34.

Honek A., Jarosik V., Martinova Z. \& Novak I. 2002: Food induced variation of thermal constants of development and growth of Autographa gamma (Lepidoptera: Noctuidae) larvae. - Eur. J. Entomol. 99: 241-252.

Hughes G.E., Bale J.S. \& Sterk G. 2009: Thermal biology and establishment potential in temperate climates of the predatory mirid Nesidiocoris tenuis. - BioControl 54: 785-795.

Jakobsen L., BrogaArd M., EnKegaArd A. \& Aaslyng J.M. 2006: Dynamic and traditional greenhouse climate regimes: Influx of thrips (Thysanoptera). - HortScience 41: 389-393.

Lalouette L., Kostal V., Colinet H., Gagneul D. \& Renault D. 2007: Cold exposure and associated metabolic changes in adult tropical beetles exposed to fluctuating thermal regimes. - FEBS J. 274: 1759-1767.

Manrique V., Cuda J.P., Overholt W.A. \& Diaz R. 2008: Temperature-dependent development and potential distribution of Episimus utilis (Lepidoptera: Tortricidae), a candidate biological control agent of Brazilian peppertree (Sapindales: Anacardiaceae). - Fla Environ. Entomol. 37: 862-870.

Mansfield S., Scholz B., Armitage S. \& Johnson M.L. 2007: Effects of diet, temperature and photoperiod on development and survival of the bigeyed bug, Geocoris lubra. - BioControl 52: 63-74.

Mead F.W. 2008: Big Eyed Bug, Geocoris spp. (Insecta: Hemiptera: Lygaeidae). EENY 252 document. University of Florida, Gainesville, 6 pp.

Mendes S.M., Bueno V.H.P. \& Carvalho L.M. 2005: Development and thermal requirements of Orius insidiosus (Say) (Hemiptera: Anthocoridae). — Rev. Brasil. Entomol. 49: 575-579 [in Portuguese].

Pendleton N.D. 2002: Development and Impact of Geocoris punctipes (Say) (Hemiptera; Lygaeidae) on Selected Pests of Greenhouse Ornamentals. Master Thesis, University of Tennessee, Knoxville, 93 pp.

Perdikis D.C. \& Lykouressis D.P. 2002: Thermal requirements for development of the polyphagous predator Macrolophus pygmaeus (Hemiptera: Miridae). - Environ. Entomol. 31: 661-667.

R Development Core Team 2011: R: A Language and Environment for Statistical Computing, Reference Index Version 2.14.0. R Foundation for Statistical Computing, Vienna. 1 CD-ROM.

Richman D.B., Hemenway R.C. \& Whitcomb W.H. 1980: Field cage evaluation of predators of the soybean looper, Pseudoplu- 
sia includens (Lepidoptera: Noctuidae). — Environ. Entomol. 9: 315-317.

Roy M., Brodeur J. \& Cloutier C. 2002: Relationship between temperature and development fate of Stethorus punctillum (Coleoptera: Coccinellidae) and its prey Tetranychus mcdalieli (Acarina: Tetranychidae). - Environ. Entomol. 31: 177-186.

SANCHEZ J.A. \& LACASA A. 2002: Modelling population dynamics of Orius laevigatus and O. albidipennis (Hemiptera: Anthocoridae) to optimize their use as biological control agents of Frankliniella occidentalis (Thysanoptera: Thripidae). - Bull. Entomol. Res. 92: 77-88.

Schuldinger-Harpaz T. \& CoOL M. 2013: Effects of global warming on predatory bugs supported by data across geographic and seasonal climatic gradients. — PLOS One 8: e66622

Schuman K.B., Kessler D. \& Baldwin I.T. 2013: Ecological observations of native Geocoris pallens and G. punctipes populations in the Great Basin Desert southwestern Utah. - Psyche 2013: $1-11$.

Sinclair B.J., Vermon P., Klok C.J. \& Chown S.L. 2003: Insects at low temperatures: an ecological perspective. - Trends Ecol. Evol. 18: 257-262.

STONER D. 1930: Spined soldier-bug reared on celery leaf-tyer. Fla Entomol. 14: 21-22.

SweEt M.H. 1960: The seed bugs: a contribution to the feeding habitats of the Lygaeidae (Hemiptera: Heteroptera). - Ann. Entomol. Soc. Am. 53: 317-321.

SweEt M.H. 2000: Economic importance of predation by bigeyed bugs (Geocoridae). In Schaefer C.W. \& Panizzi A.R. (eds): Heteroptera of Economic Importance. CRC Press, Boca Raton, pp. 713-724.

TAMAKI G. \& WeEKS R.E. 1972: Biology and ecology of two predators, Geocoris pallens Stal and G. bullatus (Say). - U.S.D.A. Agric. Tech. Bull. 1446: 46 pp.

Tillman P.G. \& Mullinix B.G. 2003: Effect of prey species on plant feeding behavior by the big-eyed bug Geocoris punctipes (Say) (Heteroptera: Geocoridae) on cotton. - Environ. Entomol. 32: 1399-1402.

Tommasini M.G. \& BenuzZini M. 1996: Influence of temperature on the development time and adult activity of Orius laevigatus. - Bull. IOBC/WPRS 17: 237-241.

Torres J.B., Silva-Torres C.S.A. \& Ruberson J.R. 2004: Effect of two prey types on life-history characteristics and predation rate of Geocoris floridanus (Heteroptera: Geocoridae). - Environ. Entomol. 33: 964-974.

Trudgill D.L., Honek A., Li D. \& van Straalen N.M. 2005: Thermal time - concepts and utility. - Ann. Appl. Biol. 146: $1-14$.

Van Lenteren J.C. 2010: Ecology: Cool Science, but Does it Help? Wageningen University, Wageningen, $44 \mathrm{pp}$.

VAN LENTEREN J.C. 2012: The state of commercial augmentative biological control: plenty of natural enemies, but a frustrating lack of uptake. - Biocontrol 57: 71-84.

YoRK G.T. 1944: Food studies of Geocoris spp., predators of the beet leafhopper. - J. Econ. Entomol. 37: 22-29.

Received February 24, 2014; revised and accepted July 11, 2014 Prepublished online August 29, 2014 